\title{
A STUDY OF THE MECHANISM OF PROTEINURIA IN PATIENTS WITH THE NEPHROTIC SYNDROME ${ }^{1}$
}

\author{
By F. P. CHINARD, 2 H. D. LAUSON, ${ }^{8}$ H. A. EDER, ${ }^{8}$ R. L. GREIF, ${ }^{8}$ AND A. HILLER * \\ (From The Hospital of the Rockefeller Institute for Medical Research, New York, N. Y.)
}

(Submitted for publication May 12, 1953; accepted December 31, 1953)

Several hypotheses have evolved from the experiments of earlier workers $(4,5)$ regarding the mechanism of proteinuria. The two hypotheses most often considered are :

1. Protein normally passes into the glomerular fluid and is completely or almost completely reabsorbed by the cells of the tubules. The concentration of protein in the glomerular fluid is considered not to exceed 25 to $30 \mathrm{mg}$. per $100 \mathrm{ml}$. (4-8). Decrease or absence of reabsorption of protein by the tubules is the cause of proteinuria (9).

2. Proteinuria occurs as the result of changes in the glomerular wall; proteins pass into the glomerular fluid in abnormally high concentration and are excreted into the urine. Tubular reabsorption (athrocytosis [10]) may occur in amounts greater or less than are assumed for the normal kidney.

It has been suggested, in addition, that protein may be secreted into the tubular lumen by diseased tubule cells. This hypothesis requires either that protein be present normally in renal interstitial fluid or that the peritubular capillaries become abnormally permeable to protein in disease. There is little to support this hypothesis; the presence of protein coagula within Bowman's capsule on histological examination is evidence against it. In pyelonephritis, where marked inflammatory changes may involve the peritubular capillaries, proteinuria is often minimal and may be absent (11).

It has also been suggested that the proteins of plasma are altered (dysproteinemia) and that the altered proteins cross the glomerular capillary walls more readily than normal plasma proteins $(e . g ., 12,13)$. The evidence in support of this sug-

\footnotetext{
1 Summaries of some of the data have been published elsewhere (1-3).

2 Present Address: The Johns Hopkins School of Medicine, Baltimore, Md.

Present Address : Cornell University Medical College, New York, N. Y.

4 Present Address: University of Illinois College of Medicine, Chicago, Ill.
}

gestion is not conclusive (7). Gitlin and Janeway (14) report that the albumin of serum, urine, and ascitic fluid from children with the nephrotic syndrome is immunochemically indistinguishable from crystallized normal human plasma albumin.

Only the first two hypotheses will be considered. Neither has been definitely confirmed or refuted though Bradley and Tyson (7) have rejected the first hypothesis on the basis of their observations that patients with the nephrotic syndrome may, under certain conditions, excrete as much as 60 $\mathrm{Gm}$. of protein per day.

In the present study, calculations have been made of the concentration of albumin in the glomerular fluid from a relationship used originally by Berglund, Scriver, and Medes (15) and by Bing (16) :

$$
\text { Minimum } \mathrm{G}_{\mathrm{alb}}=\mathrm{U}_{\mathrm{alb}} \mathrm{V} / \mathrm{GFR} \text {. }
$$

$\mathrm{G}_{\text {alb }}$ is the concentration of albumin in the glomerular fluid, $U_{\mathrm{alb}} \mathrm{V}$ is the rate of excretion of albumin in the urine, and GFR is the rate of formation of glomerular fluid. In the absence of tubular reabsorption of albumin, minimum $\mathrm{G}_{\text {alb }}$ and actual $\mathrm{G}_{\text {alb }}$ are identical. If minimum $\mathrm{G}_{\text {alb }}$ exceeds the 25 to $30 \mathrm{mg}$. per $100 \mathrm{ml}$. of total protein assumed to be present normally the first hypothesis may be excluded.

\section{METHODS}

Concentration of albumin in plasma and urine. A modification of the method of Chow (17) similar to that - of Kunkel and Ward (18) was used in the studies on patients A. McE., P. S., J. R., R. O'F., and F. de K. The antigen was a solution of human plasma albumin containing about 2 per cent alpha-1 globulin. The range of error of repeated determinations on standard solutions was within approximately \pm 10 per cent; the reproducibility of analysis of a given sample was generally of the same order. The range of error in the determination of the concentration of albumin in urine in the studies in these patients was probably no greater than \pm 20 per cent. A semi-independent check of the calculated renal clearance of albumin (hence of the urine to plasma con- 


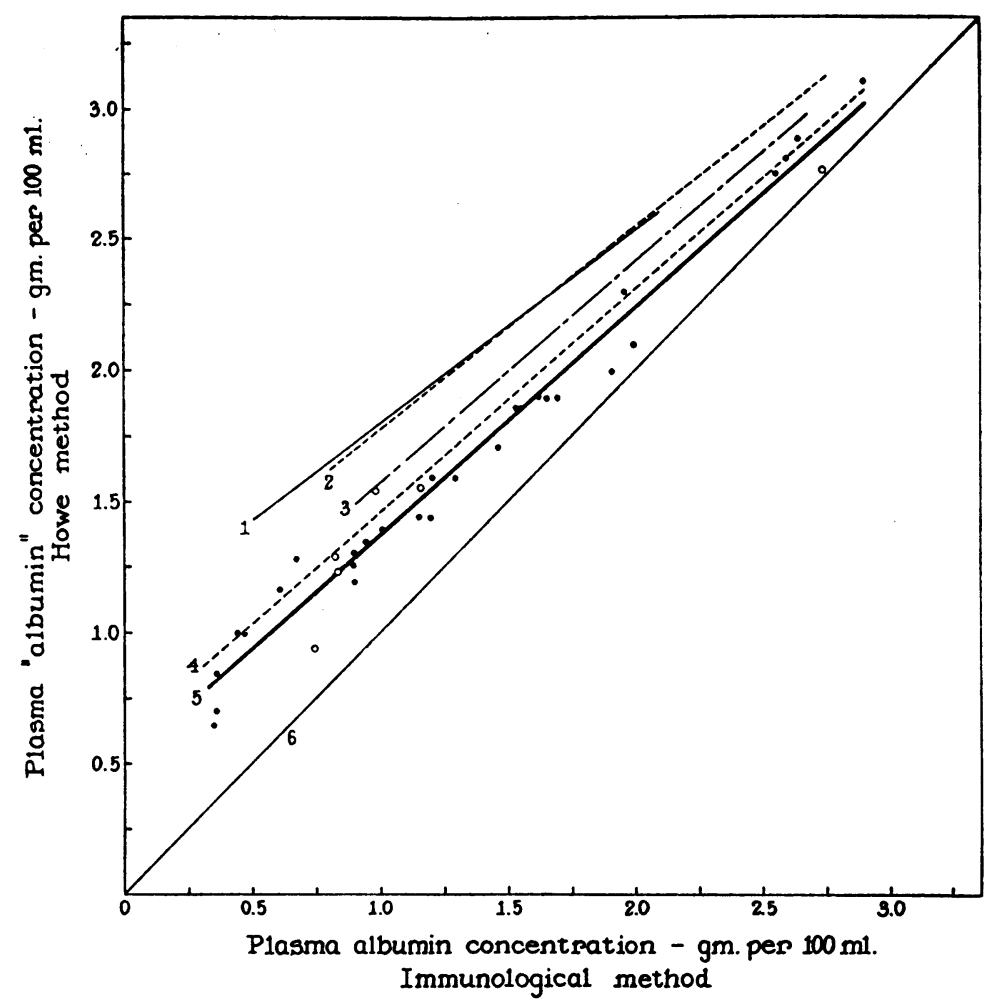

Fig. 1. Concentration of Albumin in Plasma Estimated by Two Methods: Immunochemical (AbScissa) and Howe's Fractionation (ORDinate)

Open and closed circles represent determinations on 35 plasma samples from A. McE. Line 5 represents the equation fitted to these data by the method of least squares $(y=0.50+0.87 x)$. Line 6 indicates a ratio of $1: 1$. Lines $1-4$ are curves fitted to data from four other patients : Line $1, R$. O'F. (ten values), $y=1.06+0.74 x$; line $2, F$. de $K$. (five values), $y=1.00+0.77 x$; line 3 , P. S. (six values), $y=0.73+0.84 x$; line 4 , J. R. (seven values), $y=0.62+0.85 x$; ( $x$ and $y$ are both expressed in $\mathrm{Gm}$. per $100 \mathrm{ml}$. in these equations).

centration ratios of albumin) was obtained in some experiments from the renal clearance of the dye T-1824. See (19) for data and details and for a brief discussion of the limitations of the immunochemical procedure.

In the other patients, total urine protein concentration was estimated by the biuret procedure of Hiller, Greif, and Beckman (20). An independent check of most of these results was obtained by a titrimetric procedure (21). The range of error in the total protein concentration of urine is no greater than \pm 5 per cent. In these patients the plasma albumin concentration was estimated by a modification (22) of Howe's procedure. It is recognized that the procedure gave results which were often two or three times as great as the immunochemically determined values at the low plasma albumin concentrations ( $P_{\text {atb }}$ ) obtaining in patients with the nephrotic syndrome. Figure 1 shows the relationship between the results of these two methods in five children in whom $P_{a l b}$ was increased by repeated administration of albumin. ${ }^{b}$

Concentration of endogenous "creatinine" in plasma and urine. In patients C. M., L. B., and K. S., plasma concentrations of creatinine-like chromogen were estimated by Phillips' procedure (23). A modification of the procedure of Bonsnes and Taussky (24) was used in patients A. McE., J. R., and P. S. Phillips' procedure was used for all urine samples. For a discussion of the errors in these procedures see (25). The limitations of the calculated endogenous "creatinine" clearance $\left(\mathrm{C}_{\text {er }}\right)$ as a measure of the GFR are recognized; because of the pro-

- Supplied by the National Blood Program of the American Red Cross. The albumin was administered either as a 25 per cent solution or, diluted with 5 per cent glucose, as a 10 per cent solution. The infusions were started at about 9 A.M. and lasted for 30 to 90 minutes. 
tracted nature of the experiments (some of the studies lasted more than 24 hours) there was no practical alternative. Comparative studies were made of the inulin clearance $\left(C_{1 n}\right)$ and of the "creatinine" clearance in $A$. $\mathrm{McE}$. during a control day and during a day in which albumin was given. The mean value of the ratio $\mathrm{C}_{\mathrm{cr}} / \mathrm{C}_{\mathrm{in}}$ for 28 periods was 1.29 with a range of 1.11 to 1.52 ; the ratios for 24 of the 28 periods were within 12.5 of the mean. See Figure 15 in (26) for details of this experiment. Inulin was determined by a modification of the method of Harrison (27).

Urine collections. All urine specimens were voided spontaneously. Errors in the calculated rate of urine flow are of little importance in the estimation of minimum $\mathrm{G}_{\mathrm{alb}}$ from expression (1); the urine flow enters in both numerator and denominator and thereby cancels out.

Blood samples. Venous blood samples were obtained four or five times a day during around-the-clock studies for the determination of plasma concentrations of "creatinine," albumin, and total protein. Heparin was used as anticoagulant.

Subjects. The patients were children and young adults with the syndrome of proteinuria, hypoalbuminemia, hyperlipemia, and edema; patients with hematuria, hypertension, and/or decreased urea clearances are included.

TABLE I

Data selected to show the range of minimum concentration of albumin or protein in glomerular fuid

\begin{tabular}{|c|c|c|c|c|c|c|}
\hline Patient & Date & Cer & Palb & $\frac{U_{a b b}}{C_{\text {er }}}$ & 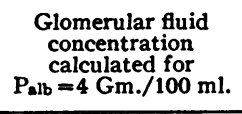 & $\begin{array}{c}\text { Time } \\
\text { relationship } \\
\text { to albumin } \\
\text { infusions }\end{array}$ \\
\hline \multirow[t]{2}{*}{$\begin{array}{l}\text { A. McE.* } \\
(\mathrm{F}, \text { age 5) }\end{array}$} & $\begin{array}{l}11-1-48 \\
11-1-48 \\
11-1-48 \\
11-1-48\end{array}$ & $\begin{array}{c}\text { ml./min. } \\
14.9 \\
28.5 \\
35.8 \\
22.6\end{array}$ & $\begin{array}{c}\text { Gm./100 ml. } \\
0.36 \\
1.94 \\
1.78 \\
0.90\end{array}$ & $\begin{array}{c}m g . / 100 \mathrm{ml} . \\
20 \\
125 \\
107 \\
50\end{array}$ & $\begin{array}{c}m g . / 100 m l \\
225 \\
260 \\
240 \\
220\end{array}$ & $\begin{array}{l}\text { Before 1st } \\
\text { After 1st } \\
\text { After 1st } \\
\text { After 1st }\end{array}$ \\
\hline & $\begin{array}{l}11-16-48 \\
11-16-48 \\
11-16-48\end{array}$ & $\begin{array}{l}27.3 \\
32.1 \\
30.0\end{array}$ & $\begin{array}{l}1.19 \\
2.48 \\
2.30\end{array}$ & $\begin{array}{r}37 \\
137 \\
115\end{array}$ & $\begin{array}{l}125 \\
220 \\
200\end{array}$ & $\begin{array}{l}\text { Before 16th } \\
\text { After 16th } \\
\text { After 16th }\end{array}$ \\
\hline \multirow[t]{2}{*}{ 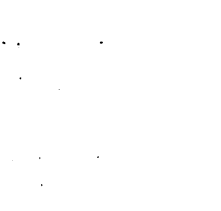 } & $\begin{array}{l}12-3-48 \\
12-3-48 \\
12-3-48\end{array}$ & $\begin{array}{l}21.9 \\
25.9 \\
40.8\end{array}$ & $\begin{array}{l}1.63 \\
2.89 \\
2.79\end{array}$ & $\begin{array}{r}46 \\
145 \\
133\end{array}$ & $\begin{array}{l}115 \\
200 \\
190\end{array}$ & $\begin{array}{l}\text { Before 33rd } \\
\text { After 33rd } \\
\text { After 33rd }\end{array}$ \\
\hline & $\begin{array}{l}12-4-48 \\
12-4-48 \\
12-4-48\end{array}$ & $\begin{array}{l}27.0 \\
26.2 \\
25.4\end{array}$ & $\begin{array}{l}2.01 \\
1.60 \\
1.52\end{array}$ & $\begin{array}{l}55 \\
50 \\
32\end{array}$ & $\begin{array}{r}110 \\
125 \\
85\end{array}$ & $\begin{array}{l}\text { None given } \\
\text { None given } \\
\text { None given }\end{array}$ \\
\hline $\begin{array}{c}\text { P. S. } \\
\text { (M, age 4) }\end{array}$ & $\begin{array}{l}12-14-48 \\
12-14-48 \\
12-14-48\end{array}$ & $\begin{array}{r}11.8 \\
14.2 \\
9.4\end{array}$ & $\begin{array}{l}0.93 \\
2.52 \\
1.68\end{array}$ & $\begin{array}{r}48 \\
193 \\
71\end{array}$ & $\begin{array}{l}205 \\
305 \\
170\end{array}$ & $\begin{array}{l}\text { Before } \\
\text { After } \\
\text { After }\end{array}$ \\
\hline $\begin{array}{c}\text { J. R. } \\
\text { (M, age 5) }\end{array}$ & $\begin{array}{l}12-14-48 \\
12-14-48 \\
12-14-48 \\
12-14-48\end{array}$ & $\begin{array}{l}38.0 \\
47.6 \\
44.1 \\
32.2\end{array}$ & $\begin{array}{l}0.43 \\
1.67 \\
1.12 \\
0.68\end{array}$ & $\begin{array}{l}11 \\
66 \\
47 \\
17\end{array}$ & $\begin{array}{l}105 \\
160 \\
170 \\
100\end{array}$ & $\begin{array}{l}\text { Before } \\
\text { After } \\
\text { After } \\
\text { After }\end{array}$ \\
\hline $\begin{array}{c}\text { K. S. } \dagger \\
(\mathrm{M}, \text { age 5) }\end{array}$ & $\begin{array}{l}10-29-47 \\
10-29-47 \\
11-12-47 \\
11-12-47\end{array}$ & $\begin{array}{l}19.3 \\
23.1 \\
23.9 \\
23.7\end{array}$ & $\begin{array}{l}1.12 \\
1.92 \\
1.28 \\
1.20\end{array}$ & $\begin{array}{l}23 \\
59 \\
40 \\
92\end{array}$ & $\begin{array}{r}85 \\
125 \\
125 \\
205\end{array}$ & $\begin{array}{l}\text { Before 1st } \\
\text { After 1st } \\
\text { Before 15th } \\
\text { After 15th }\end{array}$ \\
\hline $\begin{array}{c}\text { C. M. } \dagger \\
\text { (F. age 19) }\end{array}$ & $\begin{array}{l}11-9-47 \\
12-8-47 \\
12-8-47 \\
12-15-47 \\
12-15-47\end{array}$ & $\begin{array}{l}58.4 \\
56.1 \\
82.7 \\
68.6 \\
97.4\end{array}$ & $\begin{array}{l}0.70 \\
1.34 \\
2.21 \\
1.66 \\
2.48\end{array}$ & $\begin{array}{l}12 \\
26 \\
67 \\
23 \\
70\end{array}$ & $\begin{array}{r}70 \\
80 \\
120 \\
55 \\
115\end{array}$ & $\begin{array}{l}\text { Before 1st } \\
\text { Before 24th } \\
\text { After 24th } \\
\text { Before 31st } \\
\text { After 31st }\end{array}$ \\
\hline $\begin{array}{c}\text { L. B. } \dagger \\
(M, \text { age 19) }\end{array}$ & $\begin{array}{r}11-4-47 \\
12-10-47 \\
12-10-47 \\
12-19-47 \\
1-7-48\end{array}$ & $\begin{array}{l}84.3 \\
73.3 \\
89.5 \\
64.6 \\
66.1\end{array}$ & $\begin{array}{l}1.18 \\
1.71 \\
2.97 \\
2.95 \\
4.11\end{array}$ & $\begin{array}{r}15 \\
34 \\
120 \\
147 \\
116\end{array}$ & $\begin{array}{r}50 \\
60 \\
160 \\
200 \\
115\end{array}$ & $\begin{array}{l}\text { Before 1st } \\
\text { Before 37th } \\
\text { After 37th } \\
\text { After 46th } \\
\text { After 59th }\end{array}$ \\
\hline
\end{tabular}

* On 11-1-48, the values listed for $C_{\mathrm{er}}$ are actually values of the inulin clearance, which were on the average about 30 per cent less than the concurrent values of $C_{\text {cr }}$.

In these patients albumin in plasma was estimated by Howe's method. Figures in the fifth column represent $\mathrm{U}_{\text {prot }} \mathrm{V} / \mathrm{C}_{\mathrm{or}}$. Total urinary protein was determined by the biuret method. 

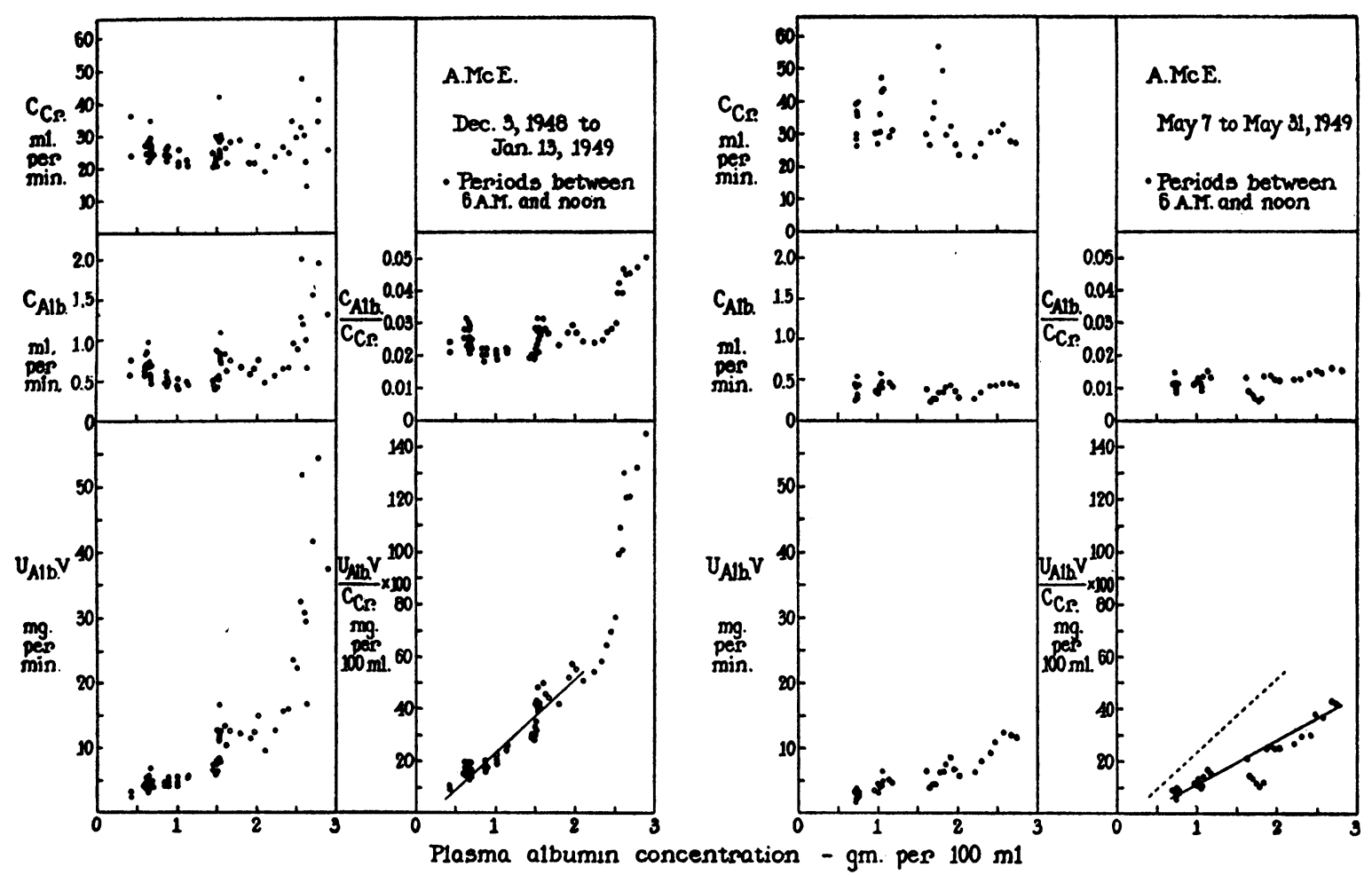

Fig. 2. Data on A. McE. (Female, Age $5 \frac{1}{2}$ Years; Duration of Nephrotic Syndrome, 28 Months)

The study on the left began a few hours following the last of 33 daily infusions of albumin $(25 \mathrm{Gm}$. per day except for last 2 which were $37.5 \mathrm{Gm}$. each) and continued at intervals during the next six weeks. Data were obtained both around-the-clock and during morning hours only (6 A.M. to noon). The study on the right began 24 hours after the last $(37.5 \mathrm{Gm}$.) of another course of daily administrations of albumin. (See Figures 1, 4, and 13 in [26] for additional background data.) The open circles represent data from morning collection periods. The solid circles represent around-the-clock data from periods outside of the hours of $6 \mathrm{~A} . \mathrm{M}$. and noon. The straight lines in the lower right of each half are curves fitted by the method of least squares to data of the morning hours only, beginning 24 hours after the last albumin administration. The interrupted line on the right is a reproduction of the curve from the December, 1948 study. The decreased slope, as well as the decreased $\mathrm{C}_{\text {a1b }} / \mathrm{C}_{\text {er, }}$ in the May, 1949 observations suggest that glomerular permeability to albumin had decreased since December, 1948. (The equations for the respective curves are: $\mathrm{U}_{\mathrm{atb}} \mathrm{V} / \mathrm{C}_{\mathrm{er}}=0.0280 \mathrm{P}_{\mathrm{abb}}-5.4$ and $\mathrm{U}_{\mathrm{abb}} \mathrm{V} / \mathrm{C}_{\mathrm{er}}=0.0168 \mathrm{P}_{\mathrm{alb}}-5.8$, where both variables are expressed as $\mathrm{mg}$. per $100 \mathrm{ml}$. The ordinate intercepts, -5.4 and $-5.8 \mathrm{mg}$. per $100 \mathrm{ml}$., do not appear to differ significantly from zero.)

\section{RESULTS}

\section{Minimum concentration of albumin or of total pro- tein in glomerular fluid}

The calculated values are shown in Table $I$. These were selected from a series of several hundred observations and inclurde the lowest and highest values found in patients with a severe form of the nephrotic syndrome. Variation of the plasma albumin concentration was achieved by the intravenous administration of concentrated human albumin. Also shown in this table are the values of $\mathrm{G}_{\text {alb }}$ which would have obtained had the plasma albumin concentration been $4.0 \mathrm{Gm}$. per $100 \mathrm{ml}$.
These last calculations are based on the fundamental assumption underlying the clearance concept that, other things being equal, the amount of a given substance crossing the glomerular capillary walls is proportional to its concentration in plasma. This assumption finds support in the experimental evidence shown in Figure 2 that the excretion of albumin $\left(U_{a b b} V\right)$ and $G_{a l b}$ (i.e., $U_{a l b} V / C_{c r}$ ) are both approximately proportional to the plasma concentration of albumin. The data in Figure 3 show similar results in acute studies. With this adjustment of the data to the circumstance of normal plasma albumin concentration all the values for the concentration of albumin and of total protein 
in glomerular fluid in Table I exceed the usually accepted normal values of 25 to $30 \mathrm{mg}$. per 100 $\mathrm{ml}$. (See [26] for additional data on A. McE. and C. M.) $)^{\bullet}$

The acute increase in the clearance of albumin $\left(\mathrm{C}_{\mathrm{alb}}\right)$ and in the ratio $\mathrm{C}_{\mathrm{alb}} / \mathrm{C}_{\mathrm{cr}}$ which occurred in the first hours following albumin administration was observed in many experiments and is seen in Figures 2 and 3. The phenomenon is associated with the acute expansion of the plasma volume occurring at the same time. This correlation is shown in Figure 4 in which the same values for $\mathrm{C}_{\mathrm{alb}} / \mathrm{C}_{\mathrm{er}}$ as were shown on the left in Figure 2 are replotted

- Use of the values for plasma albumin concentration obtained by Howe's procedure results in an underestimate of the concentration of total protein in the glomerular fluid when this adjustment is made (see Figure 1).
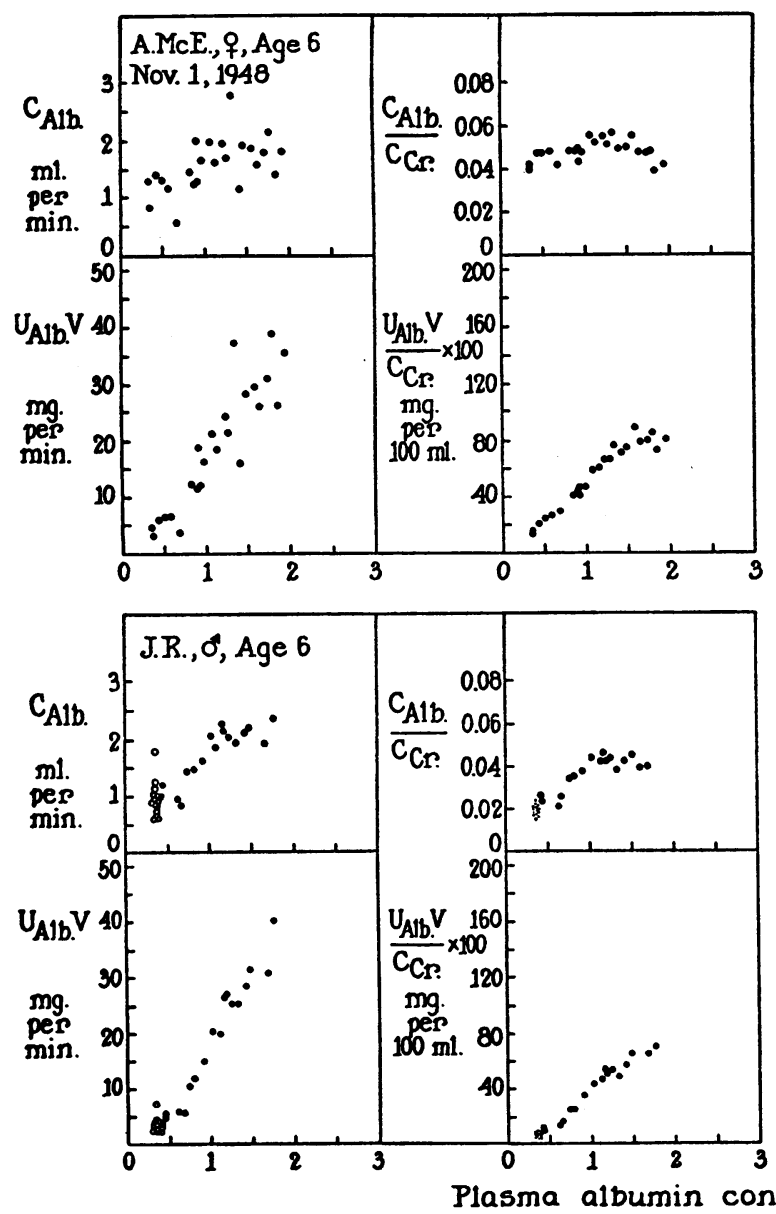

against concurrent plasma volume. Similar correlations were observed in other patients. (See [28] for details on the determination of the plasma volume.)

\section{DISCUSSION}

The question of whether proteinuria in patients with the nephrotic syndrome is the result of failure of reabsorption by the tubules of protein which normally enters the glomerular fluid or whether it indicates an increase in glomerular permeability is apparently answered by the data presented. The measurements in the severely edematous patients indicate that the minimum concentration of albumin or of total protein in the glomerular fluid (a) was often between 2 and 3 per cent of the concurrent concentration of albumin in the plasma;
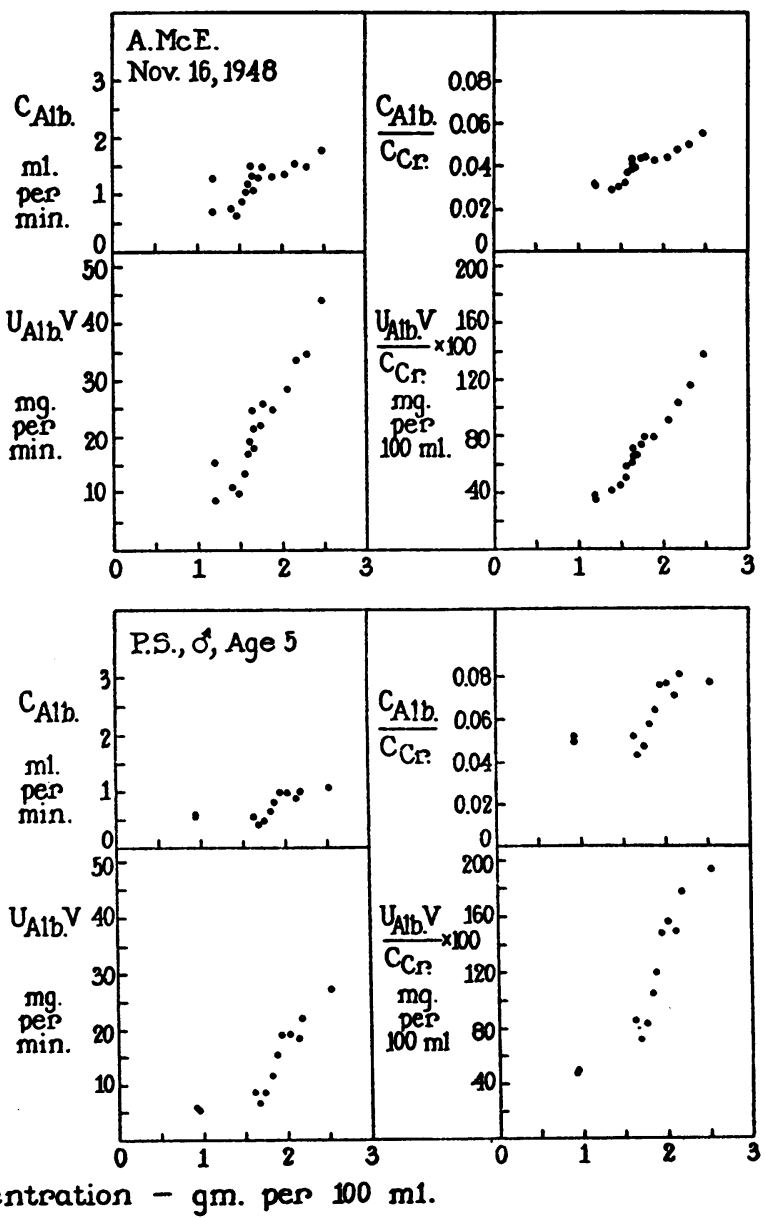

Fig. 3. Acute Effects of Intravenous Administration of Albumin on Renal Clearance and Excretion of Albumin in Relation to Paib

In the lower left quadrant the open circles and small dots represent data from a control day. See Text for details. 


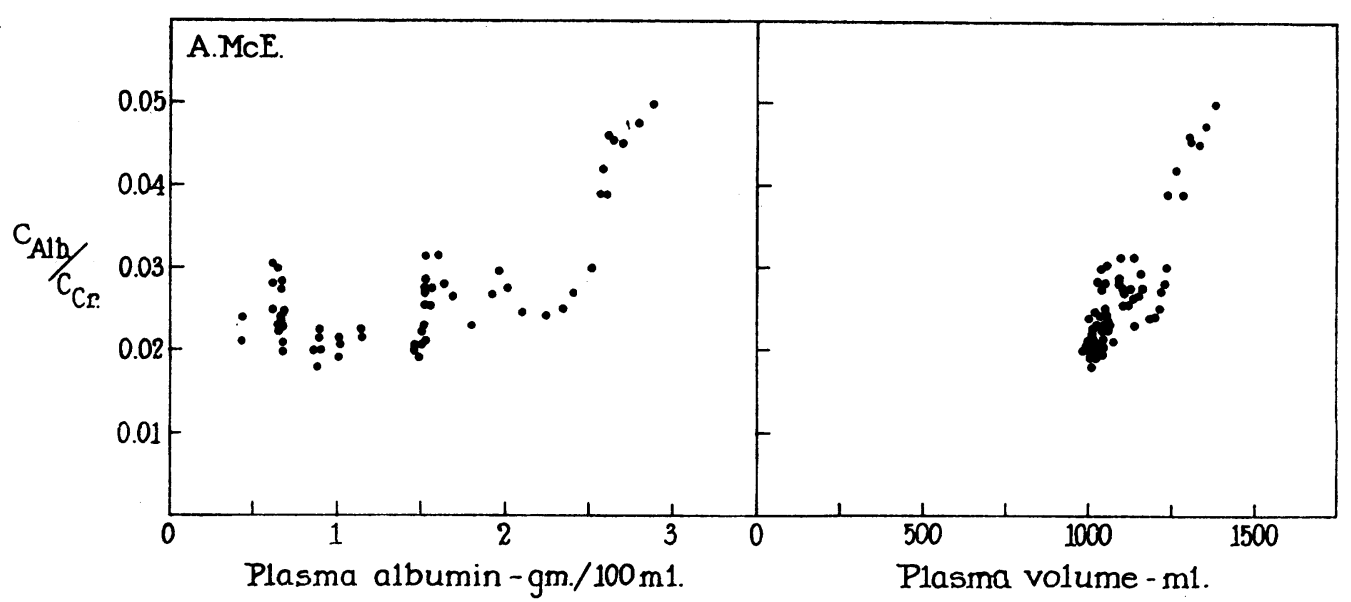

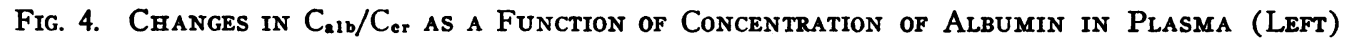
and of Plasma Volume (Right) (See Text for Details)

(b) that it fell within the range postulated for the normal kidney (i.e., under 25 or $30 \mathrm{mg}$. per 100 $\mathrm{ml}$.) only when $\mathrm{P}_{\mathrm{alb}}$ was very low ; and (c) that it varied between 100 and $200 \mathrm{mg}$. per $100 \mathrm{ml}$. when $\mathrm{P}_{\text {alb }}$ was raised by albumin administration to values one-third to two-thirds of normal. The data leave little doubt that the cause of proteinuria in these patients is an increased glomerular permeability to plasma proteins, particularly albumin.

In the patient most intensively studied (A. McE., Figures 2 and 3 ), the excretion of albumin, $U_{a l b} V$, and the ratio $\mathrm{U}_{\mathrm{alb}} \mathrm{V} / \mathrm{C}_{\mathrm{cr}}$ (i.e., $\mathrm{G}_{\mathrm{alb}}$ ), were shown to be approximately proportional to $\mathrm{P}_{\mathrm{alb}}$ as the latter decreased slowly during several weeks after cessation of albumin administration. The clearances of albumin and endogenous "creatinine" and the ratio $\mathrm{C}_{\mathrm{alb}} / \mathrm{C}_{\mathrm{er}}$ remained relatively constant, except for diurnal variation, during each of the two periods of observation. The simplest interpretation of these data is that albumin passes into glomerular fluid in amounts greater than in normal individuals and undergoes relatively little reabsorption on passage down the tubules.

That some tubular reabsorption can occur is strongly suggested by the morphologic experiments referred to in the introduction; the present results are not incompatible with this concept. However, if the tubular reabsorptive process should prove to have a relatively fixed limiting rate, $R_{\max }$, our data would indicate that its value in patients with the nephrotic syndrome must be quite small compared to the amount entering the glomerular fluid, particularly when this amount increases as $\mathbf{P}_{\mathrm{alb}}$ is elevated towards normal by administration of concentrated albumin (or when, in the initial hours or days of the disease, $\mathrm{P}_{\mathrm{alb}}$ has not yet become extremely reduced). Moreover, in these circumstances, $R_{\max }$ would be small compared to the rate of excretion. The data, however, are too inaccurate to provide more than a semi-quantitative estimate of the magnitude of this hypothetical $R_{\max }$. They are also inadequate to refute the widely-held view that normal tubules may be capable of recovering as much as $30 \mathrm{mg}$. of protein per $100 \mathrm{ml}$. of glomerular fluid formed. However, the data do indicate that a total loss of this postulated reabsorptive capacity could not possibly account for the rate of albumin excretion observed in patients with the nephrotic syndrome after the administration of concentrated albumin.

Another conceivable reabsorptive mechanism is one in which the rate of reabsorption is approximately proportional to the rate at which albumin enters the glomerular fluid or to the concentration of albumin in the fluid passing down the tubules. In either case, the type of data herein presented would give no indication of the magnitude of the rate at which the tubules recover albumin. It is possible that a steady state may be established between the concentration of albumin in the lumen of the tubules and that in the tubule cells; this steady state would not necessarily be achieved nearly instantaneously as it is considered to be in the case of glucose. It might take hours or even days for such proportionality to become established.

The possible implications of the acute increases 
in $\mathrm{C}_{\mathrm{alb}} / \mathrm{C}_{\mathrm{cr}}$ observed during the hours following albumin infusion will be discussed in detail elsewhere (29). At the present it seems reasonable to suggest that the permeability of the capillary walls is changed reversibly during this time. The association of the increased $\mathrm{C}_{\mathrm{alb}} / \mathrm{C}_{\mathrm{cr}}$ with increased plasma volume and the fact that $\mathrm{C}_{\mathrm{cr}}$ increases in spite of the increase in plasma albumin concentration (and hence increase in colloid osmotic pressure) suggest that the determinant of the increase in permeability is an increase in glomerular capillary pressure. Possibly, as a result of this increase in pressure, the capillary walls are stretched and the permeability thereby increased as suggested by others $(30,31)$.

\section{SUM MARY}

The renal clearance of albumin has been studied in patients with the nephrotic syndrome. The minimum concentration of albumin in the glomerular fluid has been calculated from the rate of excretion of albumin and the endogenous creatinine-like chromogen clearance $\left(\mathrm{C}_{\mathrm{cr}}\right)$. The concentrations, adjusted to the values which, other factors remaining constant, would obtain at the normal plasma albumin concentration of $4.0 \mathrm{Gm}$. per $100 \mathrm{ml}$., are considerably greater than the 25 to $30 \mathrm{mg}$. per 100 $\mathrm{ml}$. assumed to be normally present. It is concluded that proteinuria in these patients occurs as the result of an increase in the permeability of the glomerular capillary walls to protein rather than solely as the result of a decrease in the reabsorption of protein by the tubules.

\section{REFERENCES}

1. Lauson, H. D., Chinard, F. P., and Eder, H. A., Renal mechanism of albumin excretion in patients with nephrotic syndrome. Federation Proc., 1949, $8,91$.

2. Smith, H. W., The Kidney. Structure and Function in Health and Disease. Oxford University Press, New York, 1951.

3. Barnett, H. L., Forman, C. W., and Lauson, H. D., The nephrotic syndrome in children in Levine, S. Z. (ed.), Advances in Pediatrics, Chicago, Yearbook Publishers, Inc., Vol. V, 1952, p. 53.

4. Bott, P. A., and Richards, A. N., The passage of protein molecules through the glomerular membranes. J. Biol. Chem., 1941, 141, 291.

5. Walker, A. M., Bott, P. A., Oliver, J., and MacDowell, M. C., The collection and analysis of fluid from single nephrons of the mammalian kidney. Am. J. Physiol., 1941, 134, 580.

6. Dock, W., Proteinuria and the associated renal changes. New England J. Med., 1942, 227, 633.

7. Bradley, S. E., and Tyson, C. J., The "nephrotic syndrome." New England J. Med., 1948, 238, 223 and 260.

8. Oliver, J., New directions in renal morphology: A method, its results and its future. Harvey Lectures, 1944-1945, series 40, 102.

9. Addis, T., The mechanism of proteinuria. Proc. Nat. Acad. Sc., 1949, 35, 194.

10. Gérard, P., Comparative histophysiology of the vertebrate nephron. J. Anat., 1936, 70, 354.

11. Raaschou, F., Pyelonephritis chronica uden Proteinuri. Nord med., 1945, 25, 457.

12. Addis, T., Glomerular Nephritis, Diagnosis and Treatment. New York, Macmillan Co., 1948.

13. Wuhrmann, F., and Wunderly, C., Neuere klinische Untersuchungen über die Proteinurie. Bull. schweiz. Akad. d. med. Wissensch., 1950, 6, 254.

14. Gitlin, D., and Janeway, C. A., An immunochemical study of the albumins of serum, urine, ascitic fluid and edema fluid in the nephrotic syndrome. J. Clin. Invest., 1952, 31, 223.

15. Berglund, H., Scriver, W. de M., and Medes, G., Proteinuria and plasma proteins in The Kidney in Health and Disease, Berglund et al., Philadelphia, Lea \& Febiger, 1935, Ch. 30, p. 473.

16. Bing, J., Studies on proteinuria. "Albuminuria." Acta med Scandinav., Suppl. 76, 1936.

17. Chow, B. F., The determination of plasma or serum albumin by means of a precipitin reaction. J. Biol. Chem., 1947, 167, 757.

18. Kunkel, H. G., and Ward, S. M., The immunological determination of human albumin in biological fluids. J. Biol. Chem., 1950, $182,597$.

19. Chinard, F. P., Lauson, H. D., and Eder, H. A., Relationship of the renal clearances of T-1824 and of albumin in some patients with proteinuria. J. Clin. Invest., 1952, 31, 895.

20. Hiller, A., Greif, R. L., and Beckman, W. W., Determination of protein in urine by the biuret method. J. Biol. Chem., 1948, 176, 1421.

21. Chinard, F. P., Interactions of quaternary ammonium compounds and proteins. A simple method for the rapid estimation of urinary protein concentrations with alkyldimethylbenzylammonium compounds. J. Biol. Chem., 1948, 176, 1439.

22. Kingsley, G. R., A rapid method for the separation of serum albumin and globulin. J. Biol. Chem., 1940, 133, 731.

23. Phillips, R. A., in Peters, J. P., and Van Slyke, D. D., Quantitative Clinical Chemistry, Vol. II, Methods. Baltimore, Williams and Wilkins, 1943, Army edition.

24. Bonsnes, R. W., and Taussky, H. H., On the colorimetric determination of creatinine by the Jaffe reaction. J. Biol. Chem., 1945, 158, 581. 
25. Lauson, H. D., Sources of error in plasma creatinine determination. J. Applied Physiol., 1951, 4, 227.

26. Eder, H. A., Lauson, H. D., Chinard, F. P., Greif, R. L., Cotzias, G. C., and Van Slyke, D. D., A study of the mechanisms of edema formation in patients with the nephrotic syndrome. J. Clin. Invest., 1954, $33,636$.

27. Harrison, H. E., A modification of the diphenylamine method for determination of inulin. Proc. Soc. Exper. Biol. \& Med., 1942, 49, 111.
28. Chinard, F. P., Lauson, H. D., Eder, H. A., and Greif, R. L., Plasma volume changes following the administration of albumin to patients with the nephrotic syndrome. J. Clin. Invest., 1954, 33, 629.

29. Chinard, F. P., In preparation.

30. Krogh, A., The Anatomy and Physiology of Capillaries. New Haven, Yale University Press, 1922.

31. Davson, H., and Danielli, J. F., The Permeability of Natural Membranes. Cambridge, England, Cambridge University Press, 1943. 